\title{
ХВОРОБИ СИСТЕМИ КРОВООБІГУ ЯК ПРИЧИНА ВТРАТИ ТРУДОВОГО ПОТЕНЦІАЛУ КИЇВСЬКОї ОБЛАСТІ
}

\author{
${ }^{1}$ Київська обласна клінічна лікарня, м. Київ, Україна \\ ${ }^{2}$ Вінницький національний медичний університет ім. М. І. Пирогова, \\ м. Вінниця, Україна
}

\begin{abstract}
Мета: визначити сучасні особливості смертності, інвалідності та поширеності хвороб системи кровообігу серед населення працездатного віку Київської області порівняно з Україною.

Матеріали і методи. Аналіз смертності, інвалідності та поширеності хвороб системи кровообігу серед населення працездатного віку здійснено у динаміці за 2010-2019рр. та порівняно з Україною. За допомогою медико-статистичного методу проаналізовано статистичні дані Держкомстату України, Центру медичної статистики Міністерства охорони здоров'я України, Київського обласного центру медичної статистики.

Результати. Хвороби системи кровообігу призводять до вагомих втрат трудового потенціалу в Київській області. Вони зумовлюють кожний третій (36,2 \%) випадок смертності та кожний п'ятий (19,8 \%) випадок первинної інвалідності серед населення працездатного віку, а також складають 24,1 \% у структурі поширеності хвороб серед даної вікової групи населення Київської області.

Виявлено несприятливі тенденції у смертності, поширеності та первинній захворюваності на хвороби системи кровообігу серед працездатного населення Київської області. Рівень смертності від цієї недуги серед населення працездатного віку зріс у Київській області в 2019 р., порівняно із 2010 р., на 6,6 \% (3 189,3 до 201,8 випадку на 100000 відповідного населення). Поширеність хвороб системи кровообігу зросла впродовж 2010-2018 рр. на 15,7 \% (з 3858,0 до 4462,4 на 10000 відповідного населення), а первинна захворюваність на 5,2 \% (з 368,3 до 387,3 на 10000 відповідного населення).

Обласні рівні смертності населення працездатного віку від хвороб системи кровообігу перевищують аналогічні показники в Україні в 1,2-1,3 раза, а від ішемічної хвороби серця - у 1,5-1,7 раза. Поширеність ішемічної хвороби серця серед працездатного населення області $€$ у 1,8 раза, а цереброваскулярних хвороб - у 1,2 раза вищою, ніж в Україні, захворюваність на інсульти - в 1,7 раза, на інсраркт міокарда - у 1,5 раза вищою, ніж в Україні.

Висновки. Несприятливі динамічні тенденції у смертності та поширеності хвороб системи кровообігу серед населення працездатного віку Київської області та суттєве перевищення обласних показників середніх в Україні засвідчують необхідність удосконалення системи профрілактики ХСК та організації медичної допомоги хворим на хвороби системи кровообігу в Київській області.
\end{abstract}

КЛЮЧОВІ СЛОВА: хВороби системи кровообігу; населення працездатного віку; смертність; інвалідність; захворюваність.

Здоров'я населення працездатного віку (НПВ) як медико-соціальна та економічна проблема входить до числа пріоритетних питань кожної держави. Здоров'я НПВ враховують при обговоренні питань про національне багатство, трудовий потенціал і трудові ресурси. У результаті здоров'я НПВ $є$ інтегральним показником, який характеризує ефрективність всієї системи виробничих відносин.

Однією з найактуальніших медико-соціальних та соціально-економічних проблем України $\epsilon$ незадовільний стан здоров'я НПВ та, зокрема, негативна динаміка смертності даного контингенту $[1,9]$. Визначення сучасних закономірностей стану здоров'я НПВ повинно стати науковою основою для формування державної та регіональної політики щодо збереження та зміцнення здоров'я найбільш економічно цінної частини суспільства

(c) А. В. Іванюк, Н. М. Орлова, 2020 та визначення пріоритетів щодо інвестицій в охорону здоров'я.

Хвороби системи кровообігу (ХСК) впродовж декількох десятиліть продовжують залишатися домінуючою причиною передчасної смертності в Україні, зумовлюючи кожний третій її випадок, а ймовірність померти від ХСК у працездатному віці в Україні у рази вища, ніж у Європі в цілому [2, $8,11]$. Світовий досвід доводить, що сучасний рівень медичної допомоги дозволяє суттєво знизити обсяги передчасної смертності від ХСК [10-12].

Київська область характеризується найвищим в Україні показником втрати років життєвого потенціалу (за рахунок передчасної смертності та інвалідності) внаслідок ХСК [8]. Тому визначення особливостей смертності, інвалідності та поширеності ХСК серед НПВ Київської області та пошук можливостей зменшення втрат трудового потенціалу області за рахунок удосконалення 
організації профрілактики та лікування ХCK є актуальною медико-соціальною проблемою.

Мета дослідження: визначити сучасні особливості смертності, інвалідності та поширеності ХСК серед НПВ Київської області порівняно 3 Україною.

Матеріали і методи. Аналіз смертності, первинної інвалідності, первинної захворюваності та поширеності ХCK серед населення працездатного віку Київської області здійснено у динаміці за 2010-2019 рр. та порівняно з показниками у середньому в Україні.

Інформаційним джерелом для здійснення дослідження виступили матеріали та статистичні довідники Держкомстату України та Центру медичної статистики МО3 України, Українського державного науково-дослідного інституту медико-соціальних проблем інвалідності МОЗ України, Київського обласного центру медичної статистики [3-5].

Дослідження виконано з використанням медико-статистичного методу. У зв'язку із відміною [7] у 2018 р. фоорми державної статистичної звітності, в якій узагальнювалися статистичні дані щодо захворюваності та поширеності ХСК (ср. № 12 «Звіт про захворювання, зареєстровані у хворих, які проживають у районі обслуговування лікувально-профрілактичного закладу, за 20__ рік»), та відсутністю зведених на національному рівні даних за 2018 та 2019 рр., порівняння матеріалів щодо захворюваності та поширеності ХСК у Київській області та Україні здійснено за 2017 р.

Результати дослідження та їх обговорення. Встановлено, що хвороби системи кровообігу відіграють провідну роль у формуванні інвалідності, смертності та поширеності хвороб серед населення працездатного віку Київської області.

У 2019 р. в області у працездатному віці від ХСК померло 2051 особа, а рівень смертності від цієї причини склав 201,8 на 100000 відповідного населення. Як і у попередні роки, ХСК посіли перше місце у структурі смертності НПВ, зумовивши кожний третій $(36,2 \%)$ випадок смерті в працездатному віці.

Динамічний аналіз смертності НПВ від ХCK засвідчив, що у Київській області її рівень зріс у 2019 р., порівняно із 2010 р., на 6,6 \% (3 189,3 до 201,8 випадку на 100000 відповідного населення), тобто вдвічі швидшими темпами, ніж у середньому в Україні (табл. 1). Необхідно також відзначити, що впродовж усього періоду спостереження рівень смертності працездатного населення від ХСК у області перевищував аналогічний показник в Україні у 1,2-1,3 раза.

Аналогічні регіональні особливості втрат років потенційного життя через ХСК виявлено у дослідженнях Н. О. Рингач [8].

Таблиця 1. Смертність населення працездатного віку в Київській області та в Україні у 2010, 2015, 2019 рр.

\begin{tabular}{|c|c|c|c|c|c|}
\hline \multirow{2}{*}{ Територія } & \multicolumn{3}{|c|}{ Роки } & \multirow{2}{*}{$\begin{array}{c}\text { Абсолютний* } \\
\text { приріст } \\
2019 / 2010 \\
\end{array}$} & \multirow{2}{*}{$\begin{array}{c}\text { Темп прирост) } \\
\text { (у \%) } \\
2019 / 2010 \\
\end{array}$} \\
\hline & 2010 & 2015 & 2019 & & \\
\hline \multicolumn{6}{|c|}{ Рівень смертності НПВ від хвороб системи кровообігу (на 100000 відповідного населення) } \\
\hline Київська область & 189,3 & 193,5 & 201,8 & 12,5 & 6,6 \\
\hline Україна & 152,8 & 142,2 & 157,7 & 4,9 & 3,2 \\
\hline \multicolumn{6}{|c|}{ Рівень смертності НПВ від ішемічної хвороби серця (на 100000 відповідного населення) } \\
\hline Київська область & 129,1 & 132,5 & 139,3 & 10,2 & 7,9 \\
\hline Україна & 83,7 & 76,6 & 80,7 & $-3,0$ & $-3,6$ \\
\hline \multicolumn{6}{|c|}{ Рівень смертності НПВ від цереброваскулярних хвороб (на 100000 відповідного населення) } \\
\hline Київська область & 33,4 & 31,0 & 30,4 & $-3,0$ & $-9,0$ \\
\hline Україна & 31,7 & 28,0 & 26,6 & $-5,1$ & $-16,1$ \\
\hline
\end{tabular}

Примітка. * - абсолютна різниця між рівнями смертності в 2019 і 2010 рр. (на 100000 відповідного населення).

Особливо несприятливі тенденції щодо смертності у працездатному віці від ХСК виявлено у сільській місцевості Київської області. Рівні смертності сільського НПВ від ХСК у 1,4-1,6 раза вищі, ніж міського в Київській області та в 1,4 раза вищі, ніж серед сільського НПВ в Україні у цілому (рис. 1). Одним із чинників, які зумовлюють вищу смертність сільського населення працездатного віку від ХCK, $є$ нижча доступність спеціалізованої та високоспеціалізованої допомоги для жителів сіл. Тому актуальною медико-соціальною проблемою $є$ удосконалення організації кардіологічної допомоги населенню Київської області 3 метою підвищення її доступності, якості та ефрективності.

Високі рівні та негативна динаміка смертності НПВ від ХСК у Київській області були насамперед зумовлені несприятливою ситуацією щодо ішемічної хвороби серця (IXC) (рис. 2). Від IXC померло близько 69,0 \% серед померлих від ХCK у працездатному віці. Рівень смертності від IXC в області був стабільно вищим (у 1,5-1,7 раза), ніж в Україні, та зріс за 10 років на 7,9 \% (з 129,1 до 139,3 на 100000 відповідного населення), тоді як у середньому в країні мала місце тенденція до зниження смертності від IXC. 


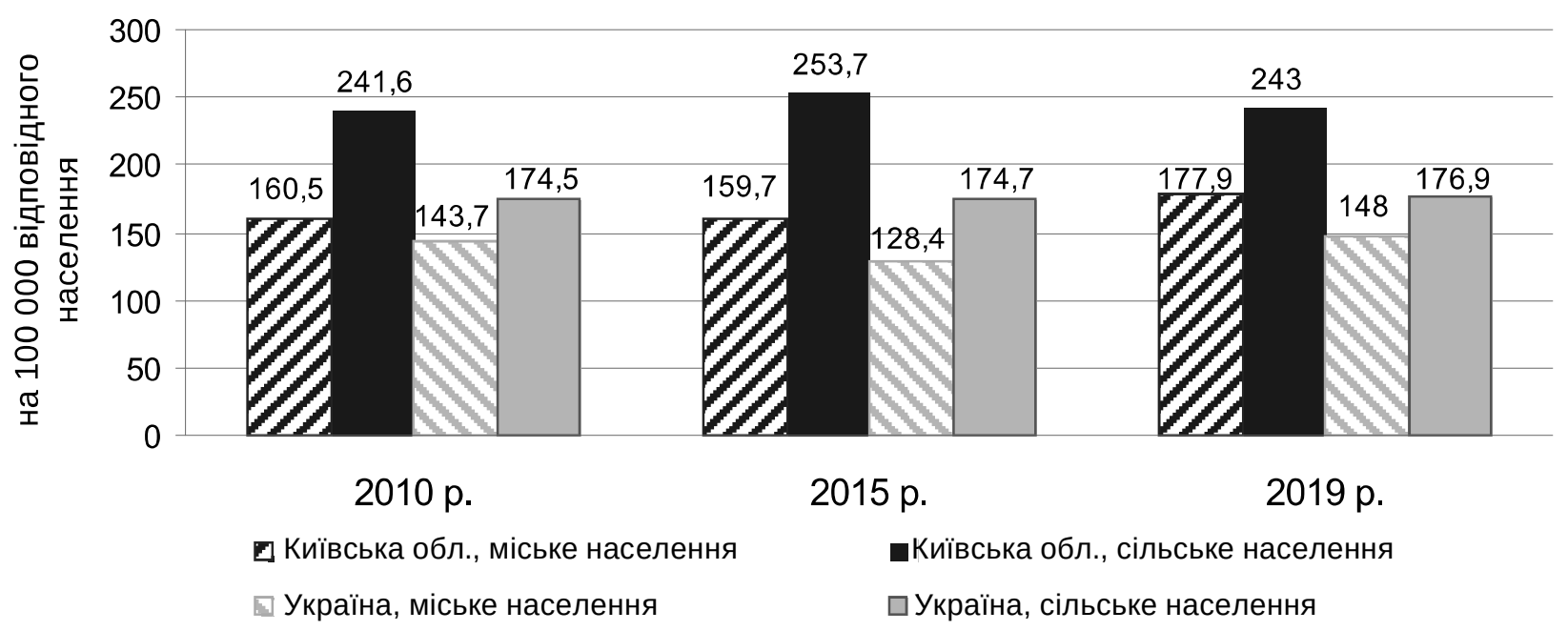

PUc. 1. Смертність населення працездатного віку від хвороб системи кровообігу в сільській і міській місцевостях як Київської області та в Україні в 2010, 2015, 2019 рр. (рівні на 100000 відповідного

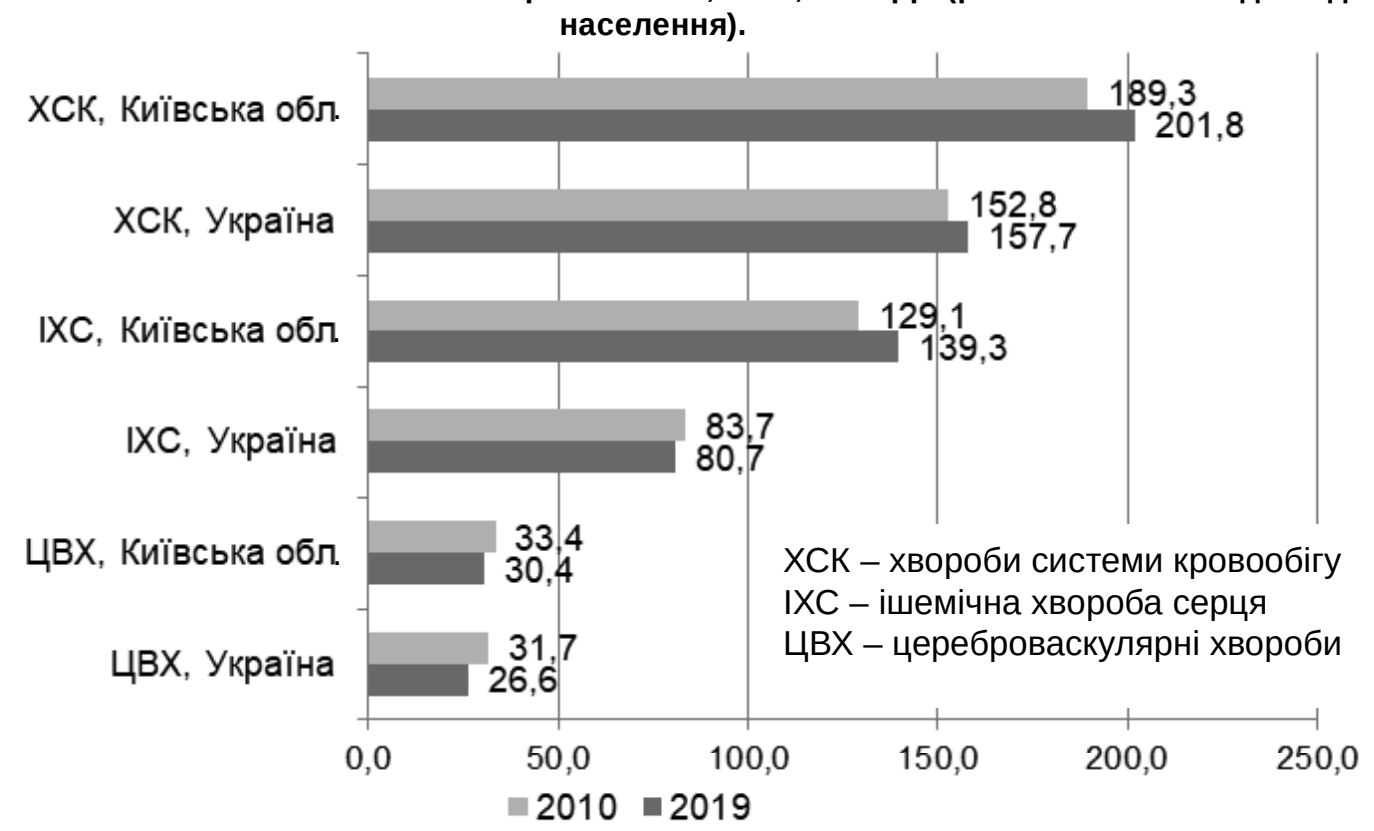

Puc. 2. Смертність від окремих хвороб системи кровообігу населення працездатного віку в Київській області та Україні у 2010, 2019 рр. (рівні на 100000 відповідного населення).

IXC належить до тих причин передчасної смертності, яким можна запобігти (avoidable mortality) як за рахунок заходів первинної профрілактики, так і вторинної $[10,11]$. Високі рівні та негативні тенденції у смертності НПВ від IXC у Київській області засвідчують необхідність запровадження регіональної програми профілактики IXC та удосконалення кардіологічної, кардіохірургічної та інтервенційної допомоги, а також збільшення її доступності для найбільш вразливих груп, у тому числі сільського населення області.

Цереброваскулярні хвороби (ЦВХ) становили другу за частотою причину смерті НПВ у середині класу ХСК. Рівні смертності НПВ від ЦВХ у Київській області впродовж всього періоду спостереження перевищували аналогічні показники в Україні (на 5,4 \% у 2010 р. і 14,3 \% у 2019 р.) і хоча й мали тенденцію до зниження, але менш виражену, ніж у середньому в країні (на 9,0 \% та 16,1 \% відповідно (табл. 1)).

Вивчення ХСК як причини інвалідизації НПВ засвідчило, що в 2019 р. ХСК призвели до фрормування інвалідності у 971 жителя Київської області. Питома вага ХСК у структурі первинної інвалідності НПВ склала 19,8 \%, а інтенсивний показник первинної інвалідності - 9,5 у розрахунку на 10000 НПВ. Половина (49,1 \%) випадків первинної інвалідності у працездатному віці була зумовлена цереброваскулярними хворобами, а третина (32,6 \%) - ішемічною хворобою серця. Впродовж періоду спостереження рівні первинної інвалідності НПВ внаслідок ХСК коливались 
у Київській області у межах 8-10,2 випадку на 10000 відповідного населення і жодного року не перевищували показники у країні в цілому (рис. 3).

Таким чином, ХCK є домінуючою причиною передчасної смертності та інвалідизації населення працездатного віку в Київській області, що зумовлює соціально-медичну та соціально-економічну вагомість ХСК, а також потребує ретельного моніторингу епідемічної ситуації щодо захворюваності та поширеності ХCK з метою обґрунтування можливостей удосконалення системи своєчасного виявлення, ефективного лікування та реабілітації хворих на ХCK для збереження трудового потенціалу області.

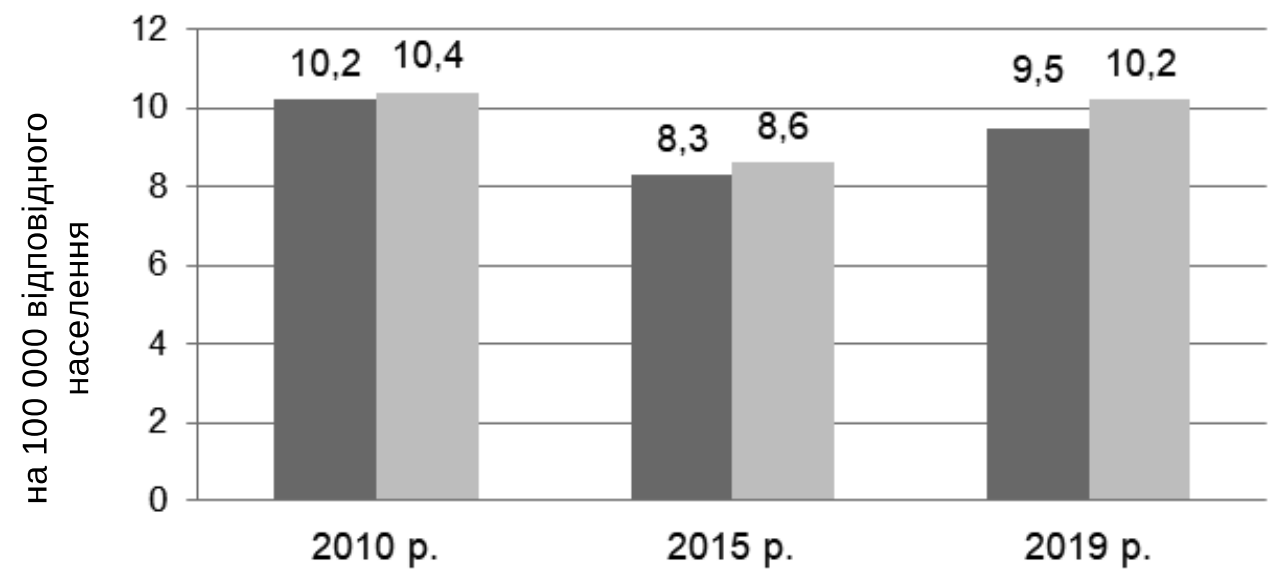

— Київська обл. Україна

Рис. 3. Первинна інвалідність внаслідок хвороб системи кровообігу населення працездатного віку Київської області та в Україні у 2010, 2015, 2019 рр. (рівні на 10000 відповідного населення).

Результати аналізу первинної захворюваності та поширеності ХСК засвідчили, що щороку в Київській області серед НПВ реєструють майже 400000 випадків ХСК (383 915 у 2019 р.), у тому числі понад 30000 (30 379 у 2019 р.) - вперше у житті. Ця патологія займає перше місце у структурі поширеності хвороб серед НПВ у Київській області (з питомою вагою 24,1 \% у 2019 р.) і складає 5,1 \% - у структурі первинної захворюваності $\mathrm{H} \Pi \mathrm{B}$.

У структурі первинної захворюваності НПВ на ХСК провідні місця у 2019 р., як і у попередні роки, посіли гіпертонічна хвороба (ГХ) (39,8 \%), ішемічна хвороба серця (26,2 \%) та цереброваскулярні хвороби (13,3 \%). У структурі поширеності ХСК їх питома вага склала в 2019 р. - 48,0 \%, 36,6 \% та 7,0 \% відповідно (рис. 4).

Порівняльний аналіз (табл. 2) епідеміологічної ситуації щодо ХСК у Київській області та Україні здійснено за 2017 р. (останній рік, коли інформація про захворюваність за фр. № 12 була узагальнена на рівні країни) виявив вищі рівні як захворюваності, так і поширеності ХСК серед населення працездатного віку області. Зокрема, інфраркти

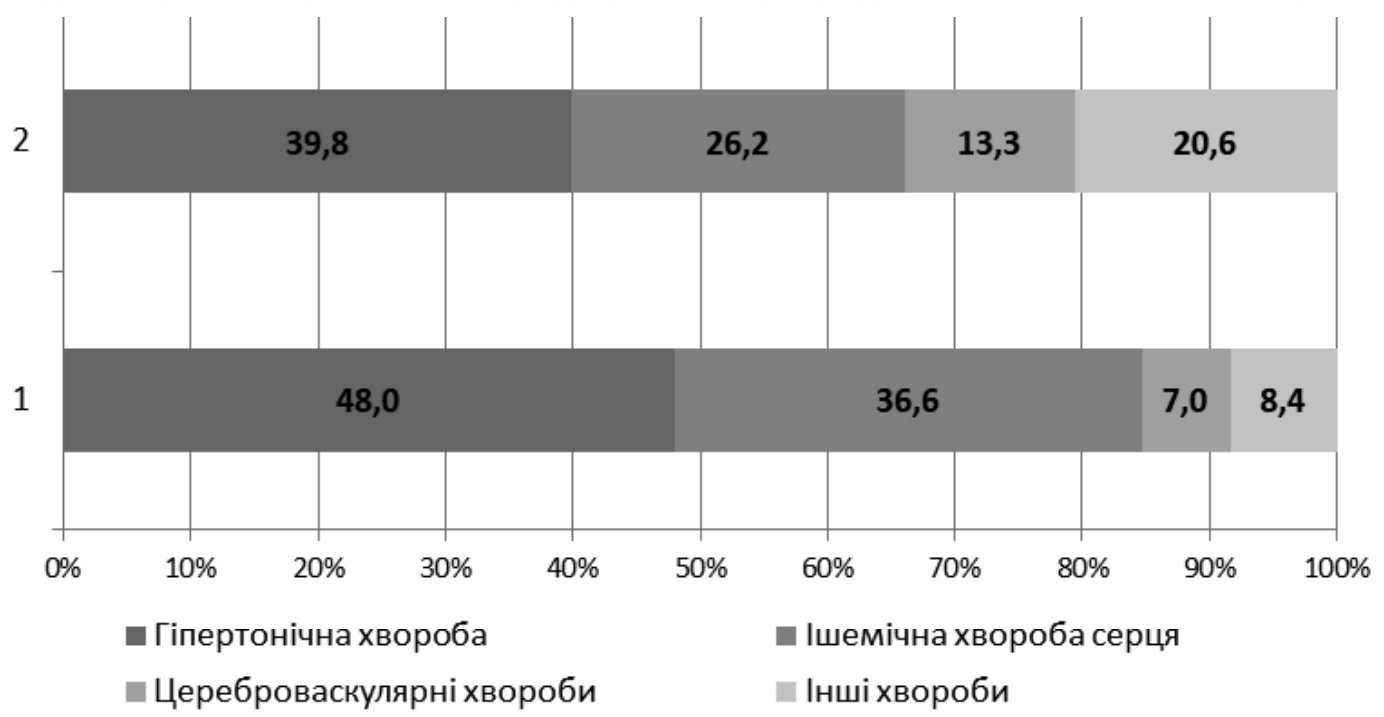

Puc. 4. Структура поширеності (1) та захворюваності (2) на хвороби системи кровообігу населення працездатного віку Київської області у 2019 р. (у \%). 
Таблиця 2. Порівняльна характеристика захворюваності та поширеності хвороб системи кровообігу серед населення працездатного віку в Київській області та в Україні у 2010, 2017 рр.

\begin{tabular}{|c|c|c|c|c|c|c|c|}
\hline \multirow{2}{*}{$\begin{array}{c}\text { Клас, нозологічна форма } \\
\text { захворювань }\end{array}$} & \multirow[t]{2}{*}{ Рік } & \multicolumn{3}{|c|}{$\begin{array}{c}\text { Первинна захворюваність } \\
\text { (рівень на } 10 \text { 000 відповідного } \\
\text { населення) }\end{array}$} & \multicolumn{3}{|c|}{$\begin{array}{c}\text { Поширеність хвороб } \\
\text { (рівень на } 10000 \text { відповідного } \\
\text { населення) } \\
\end{array}$} \\
\hline & & $\begin{array}{c}\text { Київська } \\
\text { область }\end{array}$ & Україна & $\begin{array}{c}\Pi H^{*} \\
(\mathrm{y} \%)\end{array}$ & $\begin{array}{c}\text { Київська } \\
\text { область }\end{array}$ & Україна & $\begin{array}{c}\Pi \mathrm{H}^{*} \\
(\mathrm{y} \%)\end{array}$ \\
\hline \multirow{2}{*}{$\begin{array}{l}\text { Хвороби системи } \\
\text { кровообігу І00-І199 }\end{array}$} & 2010 & 368,3 & 425,3 & 86,6 & 3858,0 & 3428,1 & 112,5 \\
\hline & 2017 & 381,1 & 350,6 & 108,7 & 4292,7 & 3335,0 & 128,7 \\
\hline \multirow{2}{*}{$\begin{array}{l}\text { Гіпертонічна хвороба (всі } \\
\text { фрорми) }\end{array}$} & 2010 & 132,2 & 193,8 & 68,2 & 1743,0 & 1886,5 & 92,4 \\
\hline & 2017 & 158,9 & 154,1 & 103,1 & 2051,6 & 1865,2 & 110,0 \\
\hline \multirow[t]{2}{*}{ Ішемічна хвороба серця } & 2010 & 107,0 & 103,4 & 103,5 & 1462,10 & 935,0 & 156,4 \\
\hline & 2017 & 100,7 & 81,1 & 124,2 & 1588,8 & 887,9 & 178,9 \\
\hline \multirow[t]{2}{*}{ Інфраркт міокарда } & 2010 & 6,7 & 5,6 & 119,6 & 6,7 & 5,6 & 119,6 \\
\hline & 2017 & 7,1 & 4,9 & 144,9 & 7,1 & 4,9 & 144,9 \\
\hline \multirow{2}{*}{$\begin{array}{l}\text { Цереброваскулярні } \\
\text { хвороби }\end{array}$} & 2010 & 42,3 & 45,3 & 93,4 & 252,1 & 244,2 & 103,2 \\
\hline & 2017 & 48,3 & 42,0 & 115,0 & 299,3 & 247,1 & 121,1 \\
\hline \multirow[t]{2}{*}{ Інсульти (всі фрорми) } & 2010 & 11,6 & 9,5 & 122,1 & 11,6 & 9,5 & 122,1 \\
\hline & 2017 & 15,8 & 9,5 & 166,3 & 15,8 & 9,5 & 166,3 \\
\hline
\end{tabular}

Примітка. * - показник наочності (виражено у відсотках відношення показника у Київській області до показника в Україні).

міокарда на Київщині діагностували серед населення працездатного віку в 1,5, а інсульти в 1,6 раза частіше, ніж у країні в цілому, а поширеність IXC у 1,7 раза перевищувала аналогічний показник в Україні. Порівняно із 2010 р. розрив у показниках захворюваності та поширеності ХCK серед НПВ у Київській області та Україні вагомо зріс за рахунок різноспрямованості динамічних тенденцій показників: у Київській області рівні захворюваності та поширеності ХСК зросли, а в Україні - знизилися.

Аналіз динаміки (табл. 3) поширеності ХCK ceред НПВ Київської області засвідчив, що впродовж 2010-2018 рр. її рівень зріс як у цілому за класом (на 15,7 \%), так і за всіма нозологічними формами та групами хвороб, які його фрормують: ГХ - на 20,9 \%, IXC - на 14,4 \%, ЦВX - на 23,2\%. Такі динамічні зміни за даним класом хвороб відбулись як за рахунок накопичення контингенту хворих (індекс хронізації захворювань за цей період зріс із 10,5 до 11,5), так і зростання первинної захворюваності на ХСК.

Найшвидшими темпами впродовж 20102018 рр. зросла первинна захворюваність на інсульти (на 58,6 \%), ЦВХ (на 21,7 \%), інфраркти міокарда (IM) (на 14,9 \%), ГX (на 13,7\%). За цей період знизилась первинна захворюваність на IXC (на 6,7 \%).

Зниження рівнів первинної захворюваності та поширеності ХCК, як і інших класів хвороб, яке спостерігали у 2019 р., можна пояснити відміною [3, 4] у 2018 р. облікової форми «Талон для реєстрації заключних (уточнених) діагнозів» (фр. № 025-2/о) та фрорми державної звітності, яка на його основі фрормувалась (фр. № 12), що призвело до неповної реєстрації випадків захворювань в області (інформація на рівні країни, як це було вказано раніше, не узагальнювалась вже 3 2018 р.). Необхідно відзначити, що ліквідація державної системи обов'язкової статистичної реєстрації ХСК унеможливлює подальше здійснення моніторингу та оцінки епідемічної ситуації щодо даної соціально вагомої патології і може негативно позначитися на своєчасності та обґрунтованості управлінських рішень, спрямованих на удосконалення організації медичної допомоги хворим із ХСК, у тому числі працездатного віку.

Важливим методом активного спостереження за контингентом хворих на ХCK є диспансеризація. Саме від ефективності реалізації диспансерного спостереження залежить частота первинної інвалідизації та летальність хворих на ХСК. Показник повноти охоплення диспансерним спостереженням хворих на ХСК має наближатись до 100 \%. У дослідженні встановлено, що в Київській області у 2017 р. диспансерним спостереженням охоплено лише 47,6 \% хворих на ХСК, у тому числі 68,5 \% хворих на ГХ, 56,0 \% - на IXC, 38,1 \% на ЦВХ. Обласні показники були суттєво нижчими, ніж в Україні у цілому (63,4 \%, 82,1 \%, 74,7 \%, 53,8 \% відповідно), що свідчить про наявність істотних недоліків в організації диспансерного спостереження за хворими на ХСК та необхідність удосконалення амбулаторно-поліклінічної допомоги для даного контингенту хворих.

\section{Висновки}

У результаті проведеного аналізу встановлено, що ХCК призводять до вагомих втрат трудо- 
Таблиця 3. Первинна захворюваність та поширеність хвороб системи кровообігу серед населення працездатного віку Київської області в 2010-2019 рр.

\begin{tabular}{|c|c|c|c|c|c|c|c|c|c|c|c|c|}
\hline \multirow{2}{*}{$\begin{array}{c}\text { Клас, нозологічна } \\
\text { формма } \\
\text { захворювань }\end{array}$} & \multicolumn{10}{|c|}{ Роки } & \multicolumn{2}{|c|}{ Тпр.* (у \%) } \\
\hline & 2010 & 2011 & 2012 & 2013 & 2014 & 2015 & 2016 & 2017 & 2018 & 2019 & $\begin{array}{l}2018 / \\
2010 \\
\end{array}$ & $\begin{array}{l}2019 / \\
2018\end{array}$ \\
\hline \multicolumn{13}{|c|}{ Рівні первинної захворюваності на 10000 населення працездатного віку } \\
\hline $\begin{array}{l}\text { Хвороби системи } \\
\text { кровообігу }\end{array}$ & 368,3 & 368,20 & 393,3 & 322,2 & 316,6 & 342,4 & 377,3 & 381,1 & 387,3 & 306,2 & 5,2 & $-20,9$ \\
\hline $\begin{array}{l}\text { Гіпертонічна хво- } \\
\text { роба (всі формии) }\end{array}$ & 132,2 & 132,5 & 153,5 & 121,9 & 129,5 & 140,8 & 158,2 & 158,9 & 150,3 & 122 & 13,7 & $-18,8$ \\
\hline $\begin{array}{l}\text { Ішемічна хвороба } \\
\text { серця }\end{array}$ & 107 & 108,5 & 113,1 & 90 & 81,6 & 91,6 & 98,6 & 100,7 & 99,8 & 80,3 & $-6,7$ & $-19,5$ \\
\hline $\begin{array}{l}\text { У тому числі } \\
\text { гострий інфраркт } \\
\text { міокарда }\end{array}$ & 6,7 & 6,5 & 6,5 & 6,6 & 6,7 & 7,2 & 7,7 & 7,1 & 7,7 & 5,8 & 14,9 & $-24,7$ \\
\hline Стенокардія & 23,2 & 24,3 & 27,3 & 19,6 & 18 & 19,3 & 23,6 & 25,5 & 24,8 & 19,2 & 6,9 & $-22,6$ \\
\hline $\begin{array}{l}\text { Цереброваску- } \\
\text { лярні хвороби }\end{array}$ & 42,3 & 43,3 & 44,2 & 38,4 & 37,7 & 40,9 & 49,4 & 48,3 & 51,5 & 40,8 & 21,7 & $-20,8$ \\
\hline $\begin{array}{l}\text { У тому числі } \\
\text { інсульти }\end{array}$ & 11,6 & 13,7 & 14,9 & 13,3 & 14,8 & 15,9 & 15,6 & 15,8 & 18,4 & 14,8 & 58,6 & $-19,6$ \\
\hline \multicolumn{13}{|c|}{ Рівні поширеності на 10000 населення працездатного віку } \\
\hline $\begin{array}{l}\text { Хвороби системи } \\
\text { кровообігу }\end{array}$ & 3858,0 & 3901,7 & 3936,1 & 3526,7 & 3610,1 & 3748,6 & 4188,6 & 4292,7 & 4462,4 & 3869,9 & 15,7 & $-13,3$ \\
\hline $\begin{array}{l}\text { Гіпертонічна хво- } \\
\text { роба (всі формии) }\end{array}$ & 1743,0 & 1771,2 & 1813,8 & 1654,6 & 1702,3 & \begin{tabular}{l|l}
3762,4 \\
\end{tabular} & 2009,7 & 2051,6 & 2108,0 & 1857,7 & 20,9 & $-11,9$ \\
\hline $\begin{array}{l}\text { Ішемічна хвороба } \\
\text { серця }\end{array}$ & 1462,1 & 1488,2 & 1490,8 & 1258,9 & 1331,5 & 1423,5 & 1523,8 & 1588,8 & 1672,1 & 1418,3 & 14,4 & $-15,2$ \\
\hline Стенокардія & 305,9 & 316,4 & 326,5 & 273,7 & 268,3 & 271,4 & 305,1 & 323,5 & 345,9 & 299,6 & 13,1 & $-13,4$ \\
\hline $\begin{array}{l}\text { Цереброваску- } \\
\text { лярні хвороби }\end{array}$ & 252,10 & 261,70 & 266,2 & 231,4 & 257,5 & 260,2 & 286,30 & 299,30 & 310,50 & 269,0 & 23,2 & $-13,4$ \\
\hline
\end{tabular}

Примітка. * - темп приросту рівня захворюваності та поширеності (у \%).

вого потенціалу в Київській області та становлять актуальну соціально-медичну та соціально-економічну проблему. ХСК зумовлюють кожний третій (36,2 \%) випадок смерті та кожний п'ятий $(19,8 \%)$ випадок первинної інвалідності серед населення працездатного віку, а також складають $24,1 \%$ у структурі поширеності хвороб серед даної вікової групи населення Київської області.

Епідемічна ситуація щодо ХСК на Київщині $€$ значно напруженішою, ніж у середньому в Україні. Обласні рівні смертності НПВ від ХСК перевищують аналогічні показники в Україні у 1,2-1,3 раза, а від ішемічної хвороби серця - в 1,5-1,7 раза. Поширеність ішемічної хвороби серця у області $\epsilon$ у 1,8 раза, а цереброваскулярних хвороб у 1,2 раза вищою, ніж в Україні, захворюваність на інсульти - в 1,7 раза, на інфраркти міокарда у 1,5 раза вищою, ніж в Україні.

Упродовж 2010-2019 рр. виявлено несприятливі тенденції у смертності, поширеності та первинній захворюваності на ХСК працездатного населення Київської області.

Рівень смертності від ХСК у Київській області зріс у 2019 р., порівняно 32010 р., на 6,6 \% (3 189,3 до 201,8 випадку на 100000 відповідного населення). Високі рівні та несприятлива динамі- ка смертності НПВ від ХСК у Київській області насамперед зумовлені ішемічною хворобою серця.

Аналіз динаміки поширеності ХСК серед НПВ Київської області засвідчив, що впродовж 20102018 рр. її рівень зріс як у цілому за класом (на 15,7 \%, з 3858,0 до 4462,4 на 10000 відповідного населення), такі за всіма провідними нозологічними формами та групами хвороб, які його формують: гіпертонічної хвороби - на 20,9\%, ішемічної хвороби серця - на 14,4 \%, цереброваскулярних хвороб - на 23,2 \%. Швидкими темпами впродовж 2010-2018 рр. зростала і первинна захворюваність на інсульти (на 58,6 \%), цереброваскулярні хвороби (на 21,7 \%), інсраркт міокарда (на 14,9 \%), гіпертонічну хворобу (на 13,7 \%).

Несприятливі динамічні тенденції у смертності та поширеності ХСК серед НПВ Київської області та суттєве перевищення обласних показників середніх в Україні засвідчують необхідність удосконалення системи профрілактики та організації медичної допомоги пацієнтам із хворобами системи кровообігу в Київській області.

Необхідно відзначити, що ліквідація державної системи обов'язкової статистичної реєстрації ХСК унеможливлює подальше здійснення моніторингу та оцінки епідемічної ситуації щодо да- 
ної соціально вагомої патології і може негативно позначитися на своєчасності та обґрунтованості управлінських рішень, спрямованих на удосконалення організації медичної допомоги хворим із ХCK, у тому числі працездатного віку.
Перспективи подальших досліджень полягають у використанні отриманих результатів для обґрунтування концептуальних підходів до удосконалення первинної та вторинної профрілактики ХСК і організації кардіологічної та кардіохірургічної допомоги населенню Київської області.

\section{Список літератури}

1. Дудник С. В. Хвороби системи кровообігу як соціально-медична проблема / С. В. Дудник, І. І. Кошеля // Україна. Здоров'я нації. - 2017. - № 3 (44). - С. 20-21.

2. Коваленко В. М. Серцево-судинні хвороби: медично-соціальне значення та стратегія розвитку кардіології в Україні / В. М. Коваленко, А. П. Дорогой // Український кардіологічний журнал. - 2016. - Додаток 3. - С. 5-14.

3. Основні показники інвалідності та діяльності медико-соціальних експертних комісій України за 2019 рік : аналітикоінформаційний довідник / А. В. Іпатов, О. М. Мороз, І. Я. Ханюкова та ін. ; за редакцією головного спеціаліста 3 питань медичної допомоги населенню Департаменту реалізації політики Р. Я. Перепеличної. - Дніпро : Акцент ПП, 2020. - 184 с.

4. Показники здоров'я населення та використання ресурсів охорони здоров'я в Київській області за 2010-2019 роки [Електронний ресурс]. - Режим доступу : http://kocms.kiev.ua/?page_id=11494.

5. Показники здоров'я населення та використання ресурсів охорони здоров'я в Україні за 2010-2019 роки [Електронний ресурс]. - Режим доступу : http://medstat.gov.ua/ukr/statdov_r.html.

6. Про внесення змін до деяких наказів Міністерства охорони здоров'я України : наказ Міністерства охорони здоров'я від 26.01.2018 р. № 157 [Електронний ресурс]. - Режим доступу : https://zakon.rada.gov.ua/laws/show/z0182-18\#Text. 7. Про затвердження Змін до наказу Міністерства охорони здоров'я України від 10 липня 2007 р. № 378 : наказ МО3 України від 04.10.2018 р. № 1802 [Електронний ресурс]. - Режим доступу : https://zakon.rada.gov.ua/laws/show/ z1240-18\#Text.

8. Рингач Н. О. Регіональні особливості втрат років потенційного життя через передчасну смертність від основних причин в Україні / Н. О. Рингач, Л. В. Лущик // Демографрія та соціальна економіка. - 2018. - № 3 (34). - С. 39-55.

9. Теренда Н. О. Смертність від серцево-судинних захворювань як державна проблема / Н. О. Теренда // Вісник наукових досліджень. - 2015. - № 4. - С. 11-13.

10. Avoidable mortality: OECD/Eurostat lists of preventable and treatable causes of death (November 2019 version). EUROSTAT, 2019. - $21 \mathrm{p}$.

11. Cardiovascular disease in Europe: epidemiological update 2016 / Nick Townsend, Lauren Wilson, Prachi Bhatnagar [et al.] // European Heart Journal. - 2016. - Vol. 37, Issue 42. - P. 3232-3245.

12. Temporal trends in ischemic heart disease mortality in 21 world regions, 1980 to 2010: the Global Burden of Disease 2010 study / A. E. Moran, M. H. Forouzanfar, G. A. Roth [et al.] // Circulation. - 2014. - Vol. 129 (14). - P. $1483-1492$.

\section{References}

1. Dudnyk, S.V., \& Koshelya, I.I. (2017). Khvoroby systemy krovoobihu yak sotsialno-medychna problema [Diseases of the circulatory system as a socio-medical problem]. Ukraina. Zdorovia natsii - Ukraine. Nation's Health, 3 (44), 20-21 [in Ukrainian].

2. Kovalenko, V.M., \& Dorohoy, A.P. (2016). Sertsevo-sudynni khvoroby: medychno-sotsialne znachennla ta stratehila rozvytku kardiolohii v Ukraini [Cardiovascular diseases: medical and social significance and strategy of cardiology development in Ukraine]. Ukrainskyl kardiolohichnyi zhurnal - Ukrainian Journal of Cardiology, 3, 5-14 [in Ukrainian].

3. Ipatov, A.V., Moroz, O.M., \& Khanyukova, I.Ya. (2020). Osnovni pokaznyky invalidnosti ta diialnosti medyko-sotsialnykh ekspertnykh komisii Ukrainy za 2019 rik: analityko-informatsiinyi dovidnyk [Main indicators of disability and activity of medical and social expert commissions of Ukraine for 2019: analytical and information reference book]. Perepelychna, R.Ya. (Ed.). Dnipro: Aktsent PP [in Ukrainian].

4. Pokaznyky zdorovia naselennia ta vykorystannia resursiv okhorony zdorovia v Kyivskii oblasti za $2010-2019$ roky [Indicators of public health and use of health resources in Kyiv region for 2010-2019]. Retrieved from: http://kocms.kiev. ua/?page_id=11494 [in Ukrainian].

5. Pokaznyky zdorovia naselennia ta vykorystannia resursiv okhorony zdorovia v Ukraini za 2010-2019 roky [Indicators of public health and use of health resources in Ukraine for 2010-2019]. Retrieved from: http://medstat.gov.ua/ukr/statdov_ r.html [in Ukrainian].

6. (2018). Nakaz Ministerstva okhorony zdorovla vid 26.01.2018 № 157 «Pro vnesennya zmin do delakykh nakaziv Ministerstva okhorony zdorovia Ukrainy» [Order of the Ministry of Health of January 26, 2018 No. 157 «On Amendments to Certain Orders of the Ministry of Health of Ukraine»]. Retrieved from: https://zakon.rada.gov.ua/laws/show/z0182-18\#Text [in Ukrainian].

7. (2018). Nakaz MOZ Ukrayiny vid 04.10.2018 № 1802 «Pro zatverdzhennia Zmin do nakazu Ministerstva okhorony zdorovia Ukrainy vid 10 lypnia 2007 roku № 378» [Order of the Ministry of Health of Ukraine dated October, 4, 2018 No.1802 «On approval of Amendments to the order of the Ministry of Health of Ukraine dated July 10, 2007 № 378»]. Retrieved from: https://zakon.rada.gov.ua/laws/show/z1240-18\#Text [in Ukrainian].

8. Rynhach, N.O., \& Lushchyk, L.V. (2018). Rehionalni osoblyvosti vtrat rokiv potentsiinoho zhyttia cherez peredchasnu smertnist vid osnovnykh prychyn $v$ Ukraini [Regional features of loss of years of potential life due to premature mortality 
from the main causes in Ukraine]. Demohrafiia ta sotsialna ekonomika - Demography and Social Economy, 3 (34), $39-55$ [in Ukrainian].

9. Terenda, N.O. (2015). Smertnist vid sertsevo-sudynnykh zakhvoriuvan yak derzhavna problema [Mortality from cardiovascular diseases as a state problem]. Visnyk naukovykh doslidzhen - Bulletin of Scientific Research, 4, 11-13 [in Ukrainian].

10. (2019). Avoidable mortality: OECD/Eurostat lists of preventable and treatable causes of death (November 2019 version). EUROSTAT.

11. Nick Townsend, Lauren Wilson, Prachi Bhatnagar, Kremlin Wickramasinghe, Mike Rayner, Melanie Nichols, (2016). Cardiovascular disease in Europe: epidemiological update 2016. European Heart Journal, 37 (42), 3232-3245

12. Moran, A.E., Forouzanfar, M.H., \& Roth, G.A. (2014). Temporal trends in ischemic heart disease mortality in 21 world regions, 1980 to 2010: the Global Burden of Disease 2010 study. Circulation, 129 (14), 1483-1492.

\section{CARDIOVASCULAR DISEASES AS A CAUSE OF LOSS OF LABOR POTENTIAL IN KYIV REGION}

A. V. Ivanyuk ${ }^{1}$, N. M. Orlova ${ }^{2}$

${ }^{1}$ Kyiv Regional Clinical Hospital, Kyiv, Ukraine

${ }^{2}$ M. Pyrohov Vinnytsia National Medical University, Vinnytsia, Ukraine

Purpose: to determine the modern features of mortality, disability and prevalence of cardiovascular diseases (CVD) among the working age population (WAP) of Kyiv region, in comparison with Ukraine.

Materials and Methods Analysis of mortality, disability and prevalence of CVD among WAP was carried out in dynamics for 2010-2019 and in comparison with Ukraine. Statistical data of the State Statistics Committee of Ukraine, the Center of Medical Statistics of the Ministry of Health of Ukraine, and Kyiv Regional Center of Medical Statistics were analyzed using the medical-statistical method.

Results. CVD are the cause of significant losses of labor potential in Kyiv region. They account every third $(36.2 \%)$ case of death and every fifth $(19.8 \%)$ case of primary disability among the working-age population, and also account $24.1 \%$ in the structure of the prevalence of diseases among this age group of population.

Unfavorable trends in mortality, prevalence and primary morbidity of CVD among WAP in Kyiv region were revealed. The mortality rate from CVD in Kyiv region increased in 2019, compared to 2010, by $6.6 \%$ (from 189.3 to 201.8 cases per 100 thousand of WAP). The prevalence of CVD increased during 2010-2018 by $15.7 \%$ (from 3.858.0 to 4.462.4 per 10 thousand of WAP), and the primary incidence rate by $5.2 \%$ (from 368.3 to 387.3 per 10 thousand of WAP).

Regional levels of mortality from CVD exceed similar indicators in Ukraine by 1.2-1.3 times, and from ischemic heart disease (IHD) - by 1.5-1.7 times. The prevalence of ischemic heart disease in the region is 1.8 times higher than in Ukraine, cerebrovascular diseases -1.2 times, the incidence of strokes -1.7 times, myocardial infarction -1.5 times, respectively.

Conclusions. Unfavorable dynamic trends in mortality and prevalence of CVD among WAP in Kyiv region and a significant excess of regional indicators of averages in Ukraine indicate the need to improve the system of prevention and medical care for patients with CVD in Kyiv region.

KEY WORDS: cardiovascular diseases; working age population; mortality; disability; morbidity.

Рукопис надійшов до редакції 27.08.2020 p.

Відомості про авторів:

Іванюк Анатолій Вікторович - кандидат медичних наук, завідувач Центру кардіохірургії Київської обласної клінічної лікарні; тел.: +38(098) 954-62-67.

Орлова Наталія Михайлівна - доктор медичних наук, професор, профресор кафедри соціальної медицини та організації охорони здоров'я Вінницького національного медичного університету ім. М. І. Пирогова. 